\title{
Factors Influencing Organizational Climate and Job Performance: A Case of VHSE Agricultural Teachers in Kerala
}

\author{
Chhanda Charana Mahananda*, G. S. Sreedaya and Deinichwa Dkhar \\ Department of Agricultural Extension, College of Agriculture, Vellayani, Kerala Agricultural \\ University, Kerala, India \\ *Corresponding author
}

\section{A B S T R A C T}

\begin{tabular}{|c|}
\hline Keywords \\
\hline $\begin{array}{l}\text { Job performance, } \\
\text { organizational } \\
\text { climate, VHSE, } \\
\text { Agricultural } \\
\text { teachers, Factor } \\
\text { analysis, Kerala, } \\
\text { knowledge } \\
\text { management, } \\
\text { organizational } \\
\text { culture, } \\
\text { organizational } \\
\text { communication }\end{array}$ \\
\hline Article Info \\
\hline $\begin{array}{l}\text { Accepted: } \\
18 \text { July } 2020 \\
\text { Available Online } \\
10 \text { August } 2020\end{array}$ \\
\hline
\end{tabular}

Introduction

In Kerala, vocational education in agriculture focuses specifically on improving students' skills, abilities, knowledge and personality to make them employable and self-employed in the agricultural and related sectors. It can be accomplished by enhancing the efficiency of the VHSE Agricultural teachers and by
Well-trained and highly skilled teachers play a vital role in the performance of the students and the schools as teachers are considered the soul of the school and play a key part in society's upliftment and nation's growth. To intensify the effectiveness of the educational organizations it is needed to increase the efficiency of the teachers by exploring the factors that have the potency to boost the job performance of the teachers since teachers are the key personals of an educational organization. Hence, the study was conducted among 120 VHSE agricultural teachers selected from the three zones of Kerala namely; Northern zone, Central zone and Southern zone with the objectives to explore the factors that are affecting the organizational climate and the job performance of the VHSE Agricultural teachers and to know relationship among them. The study revealed three factors each influencing the organizational climate and job performance of the teachers, and also the relationship between them were found to be positive and significantly correlated. 
determination, planned and managed from the top to improve the efficiency and safety of the organization through systematic organizational process measures (Backhard, 1969).

Organizational climate may be defined as mutually agreed perceptions of the employees on their internal environmental description of an organization's practices and procedures (Schneider, 1975). It is also an internal component that influences and distinguishes the behaviour of individuals from others organization. The organizational climate is the internal work environment in which all the members, i.e. teachers, administrators and other staff, work within the organization (Selamat et al., 2013). The organizational climate is the school's identity, wherein the sense of confidence and involvement of the teachers were reflected in their performance. The organizational climate has a considerable impact on the teachers ' job performance.

According to Getzels (1958), the function of both role and character is the performance of an individual in an organization. Job performance is an expected product of a combination of factors such as personality, determination, knowledge, skill, quality of work, motivation, organizational climate and willingness to accomplish work. Teaching is multifaceted and need varieties of human traits and abilities such as teachers' mental abilities and skills, his knowledge of the subject matter, personality, beliefs, attitude, interest and relationship with students, teachers and all members of the school. Hence, for increasing the efficiency of the VHSE School, it is needed to uplift the job performance of the teachers through establishing an enlightening organizational climate in the school.

From the circumstantial explained above, the present study tries to understand the VHSE organizational system with the objectives to find out the factors influencing the organizational climate, to know the factors affecting the job performance of the teachers and to study the relationship between the profile data of teachers, organizational climate and job performance.

\section{Materials and Methods}

The study was conducted via multistage random sampling. A total of 120 VHSE agricultural teachers were selected from the three zones of Kerala namely, Northern zone, Central zone and Southern zone and three districts each were selected from the three zones, i.e., Kasaragod, Kozhikode and Malappuram district from the Northern zone; Palakkad, Thrissur and Ernakulam district from the Central zone and Thiruvananthapuram, Kollam and Kottayam district were selected from the Southern zone. Ex-post-facto research design was followed and a structured interview schedule having a 7 statements with five-point Likert scale (1 strongly disagree to 5 strongly agree) were used for organizational climate(scale developed by Kolb et al., 1974) and 7 statement for Job Performance (scale created by Sundaraswamy, 1987) with three-point Likert scale (3 More efficient, 2 Efficient and 1 Less Efficient) were used for the data collection. Likewise, age, gender, educational level and job experience (in years) were collected as the profile data of the teachers.

Statistical tools such as Factor Analysis and Correlation were applied using Statistical Package for the Social Sciences (SPSS) software. Factor analysis is a technique of interdependence whose main objective is to identify the underlying structure in the assessment among the variables (Hair et al., 2014). It also delivers the techniques to investigate the structure of interrelationships (correlations) among a large number of 
variables (test scores, test items, questionnaire responses) by identifying sets of extremely interrelated variables, known as factors.

The general purpose of factor analysis techniques is to find a way to summarize the information contain in a number of original variables into a smaller set of new, composite dimensions or factors with minimal information loss i.e. to search for and define the foundational structures or dimensions assumed to underlie the original variables.

\section{Results and Discussion}

The profile data of the VHSE Agricultural teachers found that majority of the teachers (95\%) belonged to the middle age (35-55 years) group and 72per cent of them were females. Furthermore, it was found that 59 per cent of the teachers were having a master's educational qualification and majority of the teachers (76\%) having an average (8-14 years) job experience. The result also revealed from the scored interview schedule on organizational climate that 60per cent of the teachers experience a good $(27$ - 35 score $)$ organizational climate and rest 40 per cent experience an average (17 - 26 score) organizational climate. It was also observed that half of the teachers $(50 \%)$ had a high (17 - 21 score) level of job performance whereas remaining 5 per cent and 45 per cent had a low (7 - 11 score) and medium (12 - 16 score) level of performance respectively.
Principle Axis Factoring Extraction method with Varimax rotation method were employed to find out the factors associate with the seven statements that represent the organizational climate and three factors were extracted based on the cumulative variance (about 60\%) and the eigenvalues (Table 1). Table 2 represent the rotated factor matrix, that show the selected factor loading values obtained against each statement and each factor extracted. The factor loading values were selected for each statement based on the highest scores across the row.

Table 3 represents the grouping and naming of the factors that are associated with the organizational climate. The groupings of the statements under the factors were done by selecting the statements with the selected factor loading value. Naming of the factors was given after observing the group of statements that comes under the factor. Here three factors were extracted. The first one is Organizational Culture (F1) and it represented through 4 statements that are 1, 5, 6 and 7 with factor loading value. 662, 738, 459 and. 826 respectively (Table 3 ). The second factor is Autonomy of Teachers (F2) and it represented through 2 statements that are 2 and 3 with factor loading value. 677 and. 662 respectively (Table 3) and the third factor is the Organizational Communication (F3) that characterized by only statement no.3 with the factor loading value. 711 .

Table.1 Total Variance Explained in Organizational climate

\begin{tabular}{|c|c|c|c|c|c|c|}
\hline \multicolumn{7}{|c|}{ Total Variance Explained (in Organizational climate) } \\
\hline \multirow{2}{*}{ Factor } & \multicolumn{2}{|c|}{ Extraction Sums of Squared Loadings } & \multicolumn{2}{c|}{ Rotation Sums of Squared Loadings } \\
\cline { 2 - 7 } & Eigen value & $\begin{array}{c}\text { \% of } \\
\text { Variance }\end{array}$ & $\begin{array}{c}\text { Cumulative } \\
\text { \% }\end{array}$ & Eigen value & $\begin{array}{c}\text { \% of } \\
\text { Variance }\end{array}$ & $\begin{array}{c}\text { Cumulative } \\
\text { \% }\end{array}$ \\
\hline F1 & 2.782 & 39.748 & 39.748 & 1.943 & 27.756 & 27.756 \\
\hline F2 & .783 & 11.181 & 50.929 & 1.365 & 19.500 & 47.255 \\
\hline F3 & .590 & 8.429 & 59.358 & .847 & 12.102 & 59.358 \\
\hline $\begin{array}{l}\text { Extraction Method: Principal Axis Factoring. } \\
\text { Varimax Rotated Factors }\end{array}$
\end{tabular}


Table.2 Component matrix, varimax rotated factors of organizational climate

\begin{tabular}{|c|c|c|c|c|}
\hline \multicolumn{5}{|c|}{ Rotated Factor Matrix } \\
\hline \multicolumn{2}{|r|}{ Organizational climate } & \multicolumn{3}{|c|}{ Factor } \\
\hline \multicolumn{2}{|r|}{ Statements } & F1 & F2 & F3 \\
\hline 1 & $\begin{array}{l}\text { There are not many rules, regulations, procedures and } \\
\text { activities in the school under which I must follow rather than } \\
\text { function as I see fit. }\end{array}$ & .662 & & \\
\hline 2 & $\begin{array}{l}\text { I can make decisions and solve problems without checking } \\
\text { with supervisors in each step of the work. }\end{array}$ & & .677 & \\
\hline 3 & $\begin{array}{l}\text { The school setting goals and communicating these goals to its } \\
\text { members for quality and outstanding production }\end{array}$ & & & $\begin{array}{c}.71 \\
1\end{array}$ \\
\hline 4 & $\begin{array}{l}\text { As need for leadership arise, members feel free to take } \\
\text { leadership roles and also rewarded for good work. }\end{array}$ & & $\begin{array}{c}.66 \\
2\end{array}$ & \\
\hline 5 & $\begin{array}{l}\text { Things are well organized and goals are clearly defined than } \\
\text { being disorderly, confused or messy. }\end{array}$ & .738 & & \\
\hline 6 & $\begin{array}{l}\text { Friendliness is a valued norm in the school that you can trust } \\
\text { one another and other support to one another. }\end{array}$ & .459 & & \\
\hline 7 & $\begin{array}{l}\text { The school gives value to good works of each member and } \\
\text { doesn't ignore or punish if anything is wrong. }\end{array}$ & .826 & & \\
\hline
\end{tabular}

Table.3 Grouping and naming the factors of organizational climate

\begin{tabular}{|c|c|c|}
\hline No. & F1. ORGANIZATIONAL CULTURE & $\begin{array}{l}\text { Factor } \\
\text { loading }\end{array}$ \\
\hline 1 & $\begin{array}{l}\text { There are not many rules, regulations, procedures and activities in the school } \\
\text { under which I must follow rather than function as I see fit. }\end{array}$ & .662 \\
\hline 5 & $\begin{array}{l}\text { Things are well organized and goals are clearly defined than being disorderly, } \\
\text { confused or messy. }\end{array}$ & .738 \\
\hline 6 & $\begin{array}{l}\text { Friendliness is a valued norm in the school that you can trust one another and } \\
\text { other support to one another. }\end{array}$ & .459 \\
\hline 7 & $\begin{array}{l}\text { The school gives value to good works of each member and doesn't ignore or } \\
\text { punish if anything is wrong. }\end{array}$ & .826 \\
\hline \multicolumn{3}{|c|}{ F2. AUTONOMY OF TEACHERS } \\
\hline 2 & $\begin{array}{l}\text { I can make decisions and solve problems without checking with supervisors } \\
\text { in each step of the work. }\end{array}$ & 677 \\
\hline 4 & $\begin{array}{l}\text { As need for leadership arise, members feel free to take leadership roles and } \\
\text { also rewarded for good work. }\end{array}$ & .662 \\
\hline \multicolumn{3}{|c|}{ F3. ORGANIZATIONAL COMMUNICATION } \\
\hline 3 & $\begin{array}{l}\text { The school setting goals and communicating these goals to its members for } \\
\text { quality and outstanding production }\end{array}$ & 711 \\
\hline
\end{tabular}


Table.4 Total Variance explained in job performance

\begin{tabular}{|c|c|c|c|c|c|c|}
\hline \multicolumn{7}{|c|}{ Total Variance Explained (in job performance) } \\
\hline \multirow[t]{2}{*}{ Factor } & \multicolumn{3}{|c|}{ Extraction Sums of Squared Loadings } & \multicolumn{3}{|c|}{ Rotation Sums of Squared Loadings } \\
\hline & Eigen value & $\begin{array}{c}\% \text { of } \\
\text { Variance }\end{array}$ & $\underset{\%}{\text { Cumulative }}$ & Eigen value & $\begin{array}{c}\% \text { of } \\
\text { Variance }\end{array}$ & $\underset{\%}{\text { Cumulative }}$ \\
\hline $\mathrm{F} 1$ & 2.461 & 35.160 & 35.160 & 1.516 & 21.661 & 21.661 \\
\hline $\mathrm{F} 2$ & 1.139 & 16.269 & 51.429 & 1.482 & 21.172 & 42.833 \\
\hline F3 & .755 & 10.785 & 62.214 & 1.357 & 19.381 & 62.214 \\
\hline
\end{tabular}

Table.5 Component matrix, varimax rotated factors of job performance

\begin{tabular}{|c|l|c|c|}
\hline \multicolumn{1}{|c|}{ Job performance } & \multicolumn{1}{|c|}{ Factor } \\
\hline \multicolumn{1}{|c|}{ Statement } & F1 & F2 & F3 \\
\hline 1 & $\begin{array}{l}\text { I use information to schedule suitable curricula, execute teaching policies, and use } \\
\text { resources to encourage learning for all students. }\end{array}$ & .640 \\
\hline 2 & $\begin{array}{l}\text { By addressing individual learning differences and using efficient teaching strategies, I } \\
\text { encourage student learning. }\end{array}$ & .485 & \\
\hline 3 & $\begin{array}{l}\text { I analyze assessment data to measure student progress and guide immediate and long- } \\
\text { range instruction. }\end{array}$ & .934 \\
\hline 4 & $\begin{array}{l}\text { I provide a well-managed, safe student-centered environment that is academically } \\
\text { challenging. }\end{array}$ & .491 & \\
\hline 5 & $\begin{array}{l}\text { I communicate effectively with students, staff, parents, and the community. } \\
\text { I maintain a professional personality, engage in activities for professional } \\
\text { development, show curriculum knowledge and contribute to the profession. }\end{array}$ & .823 & \\
\hline 7 & $\begin{array}{l}\text { My job of teaching results in acceptable, measurable and student progress. } \\
\text { Extraction Method: Principal Axis Factoring. } \\
\text { Rotation Method: Varimax with Kaiser Normalization. }\end{array}$ & .820 \\
\hline
\end{tabular}

Table.6 Naming the factors of job performance

\begin{tabular}{|c|c|c|}
\hline No. & F1. TEACHING SKILL & $\begin{array}{l}\text { Factor } \\
\text { loading }\end{array}$ \\
\hline 2 & $\begin{array}{l}\text { By addressing individual learning differences and using efficient teaching strategies, I encourage student } \\
\text { learning. }\end{array}$ & .485 \\
\hline 3 & I analyze assessment data to measure student progress and guide immediate and long-range instruction. & .934 \\
\hline 4 & I provide a well-managed, safe student-centered environment that is academically challenging. & .491 \\
\hline \multicolumn{3}{|c|}{ F2. COMMUNICATION SKILL } \\
\hline 5 & I communicate effectively with students, staff, parents, and the community. & .823 \\
\hline 7 & My job of teaching results in acceptable, measurable and student progress. & .737 \\
\hline \multicolumn{3}{|c|}{ F3. KNOWLEDGE MANAGEMENT } \\
\hline 1 & $\begin{array}{l}\text { I use information to schedule suitable curricula, execute teaching policies, and use resources to encourage } \\
\text { learning for all students. }\end{array}$ & .640 \\
\hline 6 & $\begin{array}{l}\text { I maintain a professional personality, engage in activities for professional development, show curriculum } \\
\text { knowledge and contribute to the profession. }\end{array}$ & .820 \\
\hline
\end{tabular}


Table.7 Correlation between profile characteristics of teachers, organizational climate and job performance

\begin{tabular}{|c|c|c|}
\hline Sl. No. & Items & Coefficient of Correlation 'r' Values \\
\hline $\mathbf{1}$ & Age & $-0.210^{*}$ \\
\hline $\mathbf{2}$ & Gender & $0.101 \mathrm{NS}$ \\
\hline $\mathbf{3}$ & Education & $-0.052 \mathrm{NS}$ \\
\hline $\mathbf{4}$ & Job experience & $0.043 \mathrm{NS}$ \\
\hline $\mathbf{6}$ & Organizational climate & 0.206 * \\
\hline & “*” significant at 5\% level, "NS" Non-significant \\
\hline
\end{tabular}

The same method i.e. Principle Axis Factoring Extraction method with Varimax rotation was employed to find out the factors associate with the seven statements that represent the job performance of the teachers and 3 factors were extracted based on the cumulative variance (about 63\%) and the eigenvalues (Table 4). Table 5 represent the rotated factor matrix, that show the selected factor loading values obtained against each statement and each factor extracted. The factor loading values were selected for each statement based on the highest scores across the row.

Table 6 represents the grouping and naming of the factors that are associated with the job performance. The grouping of the statements under the factors was done by selecting the statements with the selected factor loading value. Naming of the factors was given after observing the group of statements that comes under the factor. Here 3 factors were extracted. One is Teaching Skill (F1) and it represented through 3 statements that are 2, 3 and 4 with factor loading value, 485934 and 491 respectively (Table 6). The second factor is Communication Skill (F2) and it represented through 2 statements that are 5 and 7 with factor loading value, 823 and. 737 respectively (Table 6). And the third factor is the Knowledge Management (F3) that characterized by two statements i.e. 1 and 6 with the factor loading value, 640 and 820 respectively.
Furthermore, the correlation analysis (Table 7) showed that there was a positive and significant correlation between organizational climate and the job performance of the teachers. It was also found that there was a negative correlation between age and job performance of teachers.

It can be concluded from the above analysis that the three factors imparting organizational climate were Organizational Culture, Autonomy of Teachers and Organizational Communication and three factors impacting the job performance were Teaching Skill, Communication Skill and the Knowledge Management of teachers. It was also seen that the organizational climate showed a positively correlation with the job performance of the teacher.

All together the study pointed that, a teacher with good teaching skill, communication skill and knowledge management skill can enhance their job performance in a school having good organizational culture, autonomy toward teachers and a good organizational communication. The performance of the school increases when the performance of the teacher is higher. So for increasing the performance of the school the organizational climate of the school needs to be strengthen with preferred organizational culture, providing autonomy to teachers and establish a good organizational communication system by adopting favorable organizational policies, 
rules \& regulations and also increase the teaching skill, communication skill and knowledge management skill of the teachers by providing advanced training and capacity building programmes for upgradation of knowledge and information.

\section{References}

Backhard, R. 1969. Organizational Development: Strategies and Models. Reading, Mass, Addison Wesley Publishing Co., Boston, 119p.

Getzels, J. M. 1958. Administration as a social process. In. Halpin, A. W. (Ed.) Administrative theory in Education. Midwest Administration- centre, Chicago, $152 \mathrm{p}$.

Hair, J. F., Black, W. C., Babin, B. J. and Anderson, R. E. 2014. Multivariate Data Analysis (7th Ed.), Pearson
Education Ltd., London, pp. 106-109.

Kolb, D. A., Rubin, I. M. and Mclntyre, J. M. 1974. Organizational Psychological: an experiential approach (2 ${ }^{\text {nd }}$ Ed.). Prentice Hall Inc., New Jersey, 422p.

Scheinder, B. and Snyder, R. A. 1975. Some relationship between job satisfaction and organizational commitment. $J$. Appl. Psychol. 60: 318-328.

Selamat, N., Taufig, N. Z. and Kamalu, N. 2013. The impact of organizational climate on teachers' job performance. Educ. Res. e-Journal. 2(1):71-82.

Sundaraswamy, B. 1987. A study on need achievement and job performance of Assistant Agricultural Officers in Karnataka State. Ph.D. (Ag) thesis, Tamil Nadu Agricultural University, Coimbatore, 321p.

\section{How to cite this article:}

Chhanda Charana Mahananda, G. S. Sreedaya and Deinichwa Dkhar. 2020. Factors Influencing Organizational Climate and Job Performance: A Case of VHSE Agricultural Teachers in Kerala. Int.J.Curr.Microbiol.App.Sci. 9(08): 1725-1731.

doi: https://doi.org/10.20546/ijcmas.2020.908.198 